\title{
Congenital Zika Virus Syndrome: care in light of the Brazilian Unified Health System principles
}

\author{
Síndrome Congênita do Zika Vírus: cuidado à luz dos princípios do Sistema Único de Saúde \\ Síndrome congénito del Virus Zika: atención a la luz de los principios del Sistema Único de Salud
}

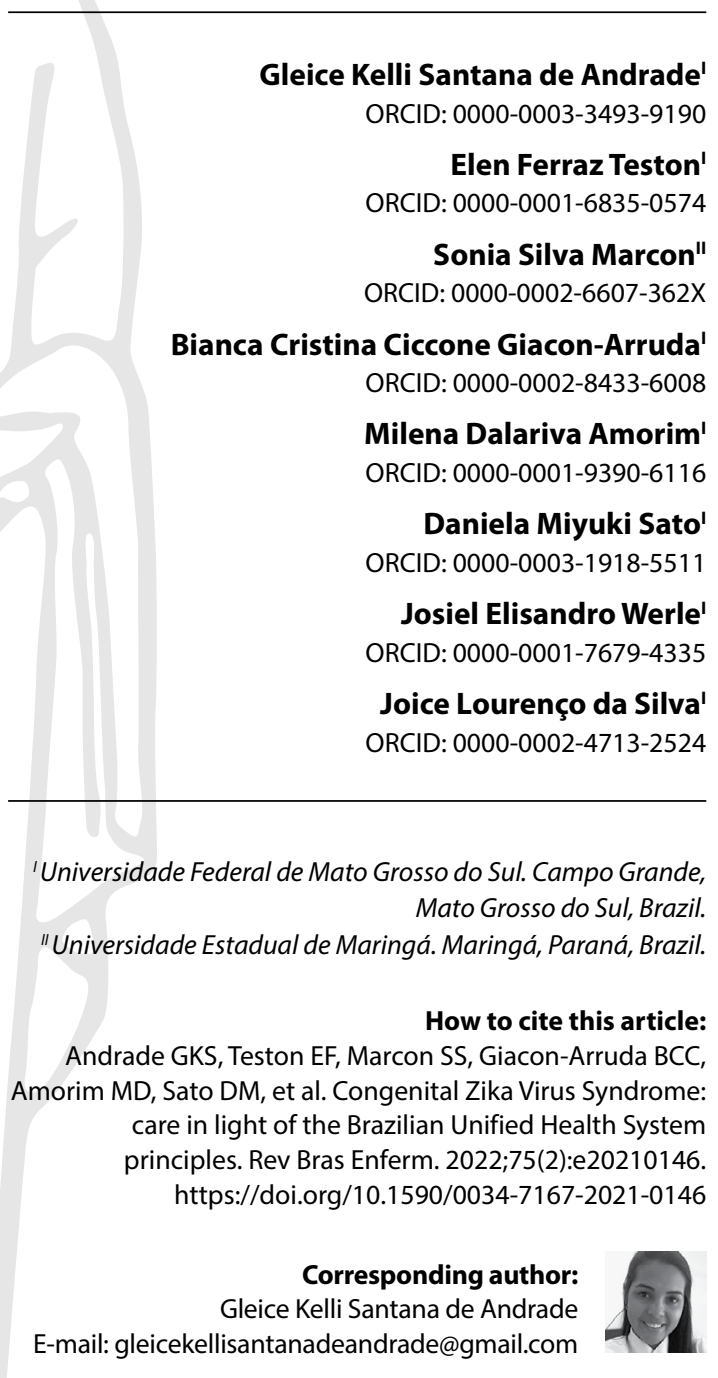

EDITOR IN CHIEF: Antonio José de Almeida Filho ASSOCIATE EDITOR: Hugo Fernandes

\begin{abstract}
Objective: to know health professionals'perceptions about care actions provided to children with Congenital Zika Virus Syndrome and their families. Methods: this is a qualitative study, carried out in a capital of center-western Brazil, based on the Unified Health System theoretical precepts. Data were collected in September and October 2020, through audio-recorded interviews with 12 health professionals from a specialized service and submitted to analysis of content, thematic modality. Results: the implementation of care actions with these children occurs through multidimensional assessment of children and their families, use of the Unique Therapeutic Project, therapeutic interventions for the development of children and the communication and exchange of interprofessional and family experiences, in addition to considering professionals prior knowledge and their search for it. Final considerations: children with CZS and their families need individualized, frequent, integrated and continuous care.
\end{abstract}

Descriptors: Zika virus; Child Care; Chronic Disease; Comprehensive Care; Unified Health System.

\section{RESUMO}

Objetivo: conhecer a percepção de profissionais de saúde acerca das ações de cuidado dispensadas às crianças com Síndrome Congênita do Zika Vírus e suas famílias. Métodos: estudo qualitativo, realizado em uma capital do centro oeste brasileiro, fundamentado nos preceitos teóricos do Sistema Único de Saúde. Os dados foram coletados em setembro e outubro de 2020, mediante entrevistas audiogravadas junto a 12 profissionais de saúde de um serviço especializado e submetidos à análise de conteúdo, modalidade temática. Resultados: a implementação de ações de cuidado junto a essas crianças ocorre mediante avaliação multidimensional da criança e sua família, utilização do Projeto Terapêutico Singular, intervenções terapêuticas para o desenvolvimento da criança e a comunicação e troca de experiências interprofissional e com a família, além de considerar o conhecimento prévio do profissional e a sua busca por ele. Considerações finais: crianças com SCZ e suas famílias necessitam de cuidados individualizados, frequentes, integrados e contínuos.

Descritores: Zika Vírus; Cuidado da Criança; Doença Crônica; Integralidade em Saúde; Sistema Único de Saúde.

\section{RESUMEN}

Objetivo: conocer la percepción de los profesionales de la salud sobre las acciones de atención que se brindan a los niños con Síndrome congénito del Virus Zika y sus familias. Métodos: estudio cualitativo, realizado en una capital del centro occidente brasileño, basado en los preceptos teóricos del Sistema Único de Salud. Los datos fueron recolectados en septiembre y octubre de 2020, a través de entrevistas grabadas con 12 profesionales de la salud de un servicio especializado y sometido a análisis de contenido, modalidad temática. Resultados: la implementación de acciones de cuidado con estos niños se da a través de la evaluación multidimensional del niño y su familia, uso del Proyecto Terapéutico Singular, intervenciones terapéuticas para el desarrollo del niño y la comunicación e intercambio de experiencias interprofesionales y familiares, además de considerar la los conocimientos previos del profesional y su búsqueda. Consideraciones finales: los niños con SCZ y sus familias necesitan cuidados individualizados, frecuentes, integrados y continuos.

Descriptores: Virus Zika; Cuidado del Niño; Enfermedad Crónica; Integralidad en Salud; Sistema Único de Salud. 


\section{INTRODUCTION}

Five years after the public health emergency caused by the Zika Virus (ZIKV) and its teratogenic power, it was concluded that microcephaly was just "the tip of the iceberg", which later led to a broader definition called Congenital Zika Syndrome $(C Z S)^{(1)}$. This is because, as affected children grow, a range of associated abnormalities arises, such as musculoskeletal malformations, seizures, dysphagia, hearing and visual impairment ${ }^{(2)}$. Thus, the challenge of providing care to children who experience chronic illness and their families is enhanced by the particularities of CZS, whose clinical, social and political consequences unfold over time ${ }^{(3)}$.

Care actions developed by the Brazilian Unified Health System (SUS - Sistema Único de Saúde) aim at encouragement and rehabilitation according to the extent of involvement by the syndrome, requiring viable flows between the demand and supply of specialized services articulated with other points of health care. Furthermore, these actions require multidisciplinary monitoring and the implementation of robust standards of support for families who are responsible for continuity and maintenance of care at home ${ }^{(4)}$.

For this reason, professionals who monitor children with multiple and continuous care needs lack permanent qualification, which will allow them to transcend biomedical care, and develop a holistic care practice that considers the family as a care unit and recognizes its role in encouraging children's development ${ }^{(5)}$.

Moreover, individuals with chronic conditions often access the different points of the Health Care Network (Rede de Atenção à Saúde) and demand interventions that consider the expanded concept of health and promote quality of life. Therefore, continuous and coordinated follow-up between the teams and between the different services is necessary so that the actions are guided by the unique needs, with a view to consolidating a universal, comprehensive and equitable care, in accordance with SUS principles ${ }^{(6-7)}$.

In the case of children with CZS, for instance, it is essential to guarantee universal access to health services at different points in the network, guaranteeing equity and comprehensive care throughout the different life cycles. To achieve this, professionals must be trained and often qualified to act according to SUS principles, with a focus on advanced practice, permeated by complex decisions based on clinical competences for care, and also having the capacity to develop actions to promote health, disease prevention, treatment and rehabilitation, within their reality and scope of action ${ }^{(8)}$.

Regarding the central theme of the study, the literature presents a wide approach on the mechanism of infection, diagnosis and prevention for ZIKV, in addition to the epidemiological and clinical characteristics of the syndrome ${ }^{(9-12)}$. In a more subjective context, studies with a qualitative approach, for the most part, explore the experiences of women diagnosed with ZIKV infection during pregnancy and the feelings experienced by them in the care of children with CZS $\mathrm{S}^{(13-16)}$. However, studies that investigate the practice of child and family care, as well as the strategies used by teams of specialized services for this care, are still incipient.

\section{OBJECTIVE}

To know health professionals' perceptions about care actions provided to children with Congenital Zika Virus Syndrome and their families.

\section{METHODS}

\section{Ethical aspects}

The study met the ethical precepts disciplined by Resolution $466 / 12$ of the Brazilian National Health Council (Conselho Nacional de Saúde) and CAAE (Certificado de Apresentação para Apreciação Ética - Certificate of Presentation for Ethical Consideration). All participants signed the Informed Consent Form. To ensure participants' anonymity, the speech records were coded with the letter " $\mathrm{P}$ " and a number indicating the order in which the interviews were carried out.

\section{Type of study}

This is a descriptive study of a qualitative nature, which used as a conceptual basis the theoretical precepts of SUS and whose description followed the Consolidated Criteria for Reporting Qualitative Research (COREQ).

\section{Methodological procedures}

\section{Study setting}

The research was carried out in a philanthropic institution specialized in rehabilitation, diagnosis, treatment, concession, adaptation and maintenance of assistive technology, located in a capital of center-western Brazil. The service has a multidisciplinary team consisting of doctors, nurses, physiotherapists, speech therapists, psychologists, occupational therapists, social workers, nutritionists, orthotics and prosthesis technicians and physical educators. It is a municipal and state reference for the healthcare network for people with intellectual, hearing, visual and physical disabilities. Services are free of charge and admission to the service occurs exclusively through referral via the Brazilian National Regulation System and the frequency of appointments is determined according to the needs of each patient.

\section{Data source}

Health professionals with higher education who carry out/carried out care to children with CZS and their families and who, at the time of data collection, were not excluded, due to the contingency adopted by the institution, during the pandemic caused by the coronavirus, were included in the study. In turn, professionals' unavailability was adopted as an exclusion criterion after three attempts to schedule an interview, on different days and times.

\section{Data collection and organization}

Initially, the principal researcher consulted the institution's general register of patients in order to identify children who have been or are being followed up as CZS (nine) in the period 2015 to June 
2020. Subsequently, through the histories of weekly and monthly visits to these children, 30 professionals eligible for the study were identified. Of these, 15 were active at the time of data collection (a doctor, a nurse, a nutritionist, a social worker, two psychologists, five physiotherapists and four occupational therapists). Then, the research was disclosed to these professionals with the support of supervisors of categories involved in care, and all were personally invited by the researcher to participate in the study, one of which did not accept to participate and two were unable to be available for the interview after three attempts to scheduling.

Data collection took place between September and October 2020, through interviews previously scheduled according to participants' availability, so as not to interfere with the work routine and carried out in a private room at the institution itself. They were audio-recorded after authorization, had an average duration of 60 minutes and performed by the main researcher, using a script consisting of questions related to participants' characterization, a guiding question, "How is the care of children with CZS and their families carried out?", and some support questions addressing strategies for implementing and maintaining care, multidisciplinary work and knowledge about the syndrome.

The end of the collection followed the sufficiency criterion, when the number of interlocutors and the quality of their reports already allowed reflecting the multiple dimensions of the object, based on the recurrence and complementarity of information ${ }^{(17)}$.

\section{Data analysis}

All interviews were transcribed in full and submitted to content analysis, thematic modality, following the steps proposed ${ }^{(18)}$. In pre-analysis, the initial ideas were systematized through material organization, followed by an exhaustive reading with the identification of the core meanings considering the objective of the study. In the material exploration stage, we proceeded to the grouping into thematic nuclei, through a meticulous process of reading, classification and aggregation of the meaning units ${ }^{(18)}$, namely: needs of families to maintain care; planning of care actions; guidance of interventions against the chronic condition; performance and communication of the multidisciplinary team; professional training for the care of children with CZS and their families.

Finally, in the stage of processing the results ${ }^{(18)}$, after articulating the empirical data with the theoretical material anchored in the research objective and in the identified themes, the category "Construction of care for children with Congenital Zika Syndrome and their families" emerged, consisting of the subcategories "Planning of care actions", "Implementation of care" and "Knowledge regarding Congenital Zika Syndrome".

\section{RESULTS}

The 12 study participants were aged between 26 and 46 years (mean 35.6 years), being 11 female, four physical therapists, four occupational therapists, two psychologists, a social worker and a nutritionist. Time from graduation ranged from three to 18 years (average of 11.6 years) and working time at the institution from 11 months to nine years (average of 5.3 years). Among the participants, 10 declared to have some specialization.
The category "Construction of care for children with Congenital Zika Virus Syndrome and their families" addresses aspects of planning, execution and knowledge about care actions aimed at children with CZS and their families and is made up of three subcategories, the which will be described below.

\section{Planning of care actions}

In this subcategory, participants pointed out some elements and strategies used to plan care actions:

\begin{abstract}
Initially, why this person is here, because often they do not know, even if it is written on paper why they were referred, sometimes even the referring physician commented something, the caregiver does not understand why he is here, so the first thing I do at the reception is to ask why you came [...]. (P10)
\end{abstract}

We carry out a multidimensional assessment, which also assesses whether this family is a barrier or a facilitator, the environment they live in, which is the school, also whether they have access to health services, to the social part [...]. (P11)

We need to know income, if they have housing, and if the patient is already receiving benefits, because if they cannot come, we already have to provide it for them faster [...] at least to minimize that they do not miss appointments [...]. (P5)

It was observed that this stage begins with the reception, knowledge and approach to the biopsychosocial context of children with CZS and their families.

Respondents also highlighted the need to retrieve children's gestational history, clinical history and current status:

As was the gestational period of this mother, there was a prenatal care, if any type of change was pointed out in the ultrasound exams or not [...] and we also ask about the child's current history, how does this mother feel the day to day with her, [...]. (P1)

Normally, you hear a little about children's history, how that pregnancy was, but the main information is how it is, what the mother is noticing at home, what medications she is taking, because depending on the medication this will interfere if this child is sleepy, it will interfere with ourcare [...] it is this information that I collect and that on top of that I will develop my entire treatment plan, the way I will conduct it [...]. (P6)

Therefore, the use of tests and assessment instruments during the planning of care actions:

[...] here comes the specific assessment of physiotherapy, we have some reflex tests, we apply it to the children according to their age at the time of assessment, and through that, we plan a conduct. (P1)

For me, an anamnesis is the main thing for a good result. Applying the appropriate assessment instruments for that child, we can even see, see a better prognosis, explain it better to this family [...]. (P12)

The family's complaints and their expectations and perspectives are fundamental in this planning:

Every time we assess patients, we ask what the mother expects from our therapy, what she wants the child to do that the child does not do yet, these things so that we can know and direct. (P2) 
Regarding the tools used for planning, participants highlighted the importance of using the Unique Therapeutic Project (PTS Projeto Terapêutico Singular):

We manage to do what we call a Unique Therapeutic Project, which is planning. You see through this reflection, these goals, what the mother expects. We are able to do this work of co-responsibility of the team where everyone participates, so everyone I say, the multidisciplinary team and the family [...]. (P12)

[...] there will always be a professional who is responsible and accompanies this patient from admission to discharge; for example, if this patient's greatest need in the assessment is cognitive, then the person responsible for PTS is a psychologist who assists and he is the one who will manage this PTS, he is the one who will discuss with the other professionals, he is the one who will sit with the family and will set the goals together [...]. (P11)

Reports show that when used routinely, PTS can support interventions and teamwork.

\section{Implementation of care}

Participants highlighted that the recognition of CZS as a chronic condition is also an important element in the construction of care for these children and their families:

[...] even though we are unable to establish a standard of normality for these children, we are able to provide the maximum quality of life and functionality, so it is important because as well as the disease that they will have for life, this care too will remain for life [...]. (P1)

This is because the focus is on offering actions that favor quality of life and that take into account the limitations in different stages of development. In this context, professionals highlighted the need for early encouragement and longitudinal monitoring, so that better results are achieved:

When this child comes to us at an early age, the child already becomes a child of longitudinal monitoring [...], for example, if they [children] are months old and come here, we can follow the chronological development and encourage what they are late, now seven years old, will be a distance from the chronological age and we will take longer, even we will not be able to put all the support they need to develop fully. (P11)

Also, interventions are developed considering the different health needs and specificities that CZS can entail:

We work more on the limitations that are caused by the sequel that Zika virus causes, so we work like this through encouragement, the prevention of deformities, stimuli, both sensory, motor, cognitive [...] visual and auditory encouragement, all of this we encourage through playing, through movements, stretching, handling. (P3)

Among the implemented care actions, participants highlighted those that favor the performance of basic activities of daily living and adaptations to the limitations caused by CZS:

This child also needs to be cognitively encouraged to see if, through this, she can have a good performance in motor coordination, even so we can see if this child can brush a tooth, comb her hair, put on clothes [...]. (P6)

Here, in occupational therapy, it offers everything to the child, everything she needs to have a daily life as close to adequate as possible; occupational therapy works with reality, the readaptation of these individuals, so we will adapt in a new reality, enable it in fact, in this new reality of theirs, because they are not being rehabilitated but empowered, we work more in this context too. (P4)

Furthermore, professionals pointed out the need to seek feedback from the family regarding care actions implemented to identify influential factors in the treatment and plan new directions:

When the mothers arrive, I always ask how you are, how you went this week, did you have any evolution, are doing all the orientations that were given, then they tell me, "Oh, started to stand up, oh, started to do that, oh is very darn, ours has improved a lot", so we need this feedback [...]. (P7)

To do so, they referred to the use of alternative resources that help the family in feedback regarding children's evolution:

[...] because the family is with the child every day, they can perceive in a simpler way some things the child needs in their daily lives, I often use the resources of home videos and they help me a lot, when it is also possible, diary, I don't take a notebook at all, a single sheet, when the family can write, [...] and I can identify in these reports a development or a therapeutic plan for this child, it also helps me a lot, because in these reports they sometimes put things that were not said during the service. (P10)

Likewise, they highlighted the importance of frequent communication between the professionals involved in care:

We need to have a sequence, the multi team is a gear and one complements the other's work, so I think that when you exchange this information, this gear is easier to be connected [...]. (P6)

It is important for the patient's evolution, because many times I may be seeing something that the physicist is not seeing, that the physiotherapist is not seeing, or else it may be giving me something that I could not observe [...]. (P7)

This is because, when the flow of communication is clearly established, there are possibilities for expansion and advancement in the development of children with CZS.

\section{Knowledge regarding Congenital Zika Syndrome}

In this category, the reports show the difficulties experienced in the early days after the emergence of CZS resulting from the lack of knowledge and specificities of the presented deficiencies.

Children [with CZS] came for us to provide care, I went to do research, study about the subject, to know what neurological aspects were affected and how this demand would be, in order to be able to provide care and receive this patient who would be assisting. (P10)

[...] a colleague arrives and says, "I saw such a thing, in the micro part, it's interesting", we'll also look for it. Talking with colleagues 
here, with the doctors, we start, "I've done everything I could do so far, is there anything you know?" [...]. (P9)

Furthermore, the experience of professional work in caring for children with sequelae similar to CZS, was identified as the basis for the provision of care actions provided to this public:

[...] and also because of the experience we already have in the child's motor care and early encouragement, because many things I've seen in the courses, are things that we have as background from undergraduate, graduate, clinical experience, we you learn a lotmore by assisting; had other types of training, but not specific to Zika. (P8)

We go straight to the prognosis part, which is what the child presents, if there is any delay, we work on that; as this type of child is born with this sequel, it is very similar to the sequel of microcephaly; so, we work in the same lineage as a child with cerebral palsy [...]. (P4)

In this context, the partnership with educational and research institutions was identified as an important element for the construction of knowledge and for the proposition of care actions in relation to $\mathrm{CZS}$ :

Our neurologist is the doctor [doctor name], she participates in the Zika virus laboratory and we have the multi residency here and the rehabilitation, our residents also participate in the Zika virus laboratory in partnership with the university, so we had a lot of knowledge in the area. (P11)

However, they were willing for specific skills:

[...] if we trained for autism, for down syndrome, why not do it for these other diseases that are reaching us as well? It's a new disease, it started a short time ago. (P5)

It's a public that despite being presenting many projects, people are still studying neurodevelopment, how this child behaves, because it's recent, five years ago, there's still a lot that we still don't know, so it's important to train these teams. (P12)

It is observed in the reports that professionals recognize the importance of approaching the theme to carry out more qualified care actions for this audience, due to their specificities.

\section{DISCUSSION}

Assistance to individuals with chronic conditions, in the different spheres of SUS, permeates several biopsychosocial factors that influence the consolidation and continuity of care actions carried out by health professionals and family members. When this condition occurs in childhood, the challenge becomes even greater, since development is influenced by individual, behavioral, genetic, environmental, social and political factors, which are gradually revealed over time ${ }^{(3)}$.

In this context, the participants of this study emphasized that care planning should start with the identification of the different needs experienced by children with CZS and their families, and the context in which they are inserted, especially favorable and unfavorable conditions for the execution and maintenance of care. In this sense, with a view to developing effective and sustainable long-term care interventions, professionals should consider the possible limitations experienced/presented by those who will be assisted ${ }^{(19)}$.

It should be noted that sometimes the life of children with complex chronic conditions is marked by the invisibility of their presence in common living spaces and restricted to hospital environments or rehabilitation spaces ${ }^{(20)}$. However, these children and their families need to be welcomed by the different points of healthcare in SUS, in particular, by the team that works in the territory where they live, in order to favor the monitoring of care actions that require continuity by the family, as they are complementary to those carried out in the rehabilitation service.

Emphatically, the participants mentioned the importance and the need to understand the experience and knowledge that the family has about children's condition, which corroborates research carried out with nurses from Primary Health Care (PHC). These nurses pointed out that to care for children with special health needs, it is important to welcome families, recognize their limitations and clarify doubts, as these actions significantly impact the quality of care provided ${ }^{(21)}$.

Thus, knowing the family's socioeconomic conditions is an important element for planning care, because when unfavorable, it increases vulnerability and hinders access to treatment. These aspects are aggravated by the lack of formal mechanisms to support families and reveal an important gap in the promotion of comprehensive care for this public ${ }^{(22-23)}$.

More than 30 years after the creation of SUS, CZS has forced a debate on the relevance of factors influencing access to services in light of multiple and complex health needs ${ }^{(24)}$. Participants in this study reported that access to health, educational and social services are a priority in the guidance of care, which reinforces the result of a research carried out in Pernambuco and Rio de Janeiro, which identified that from the perspective of mothers of children with CZS and of public network professionals, access difficulties are numerous and permeate organizational, sociocultural, geographic and economic accessibility ${ }^{(23)}$.

With regard to the strategies and tools used for care planning, professionals reported the performance of tests and application of specific and appropriate instruments for child assessment. Given the limited knowledge about the natural history of CZS in early childhood, the systematic and regular use of standardized screening or assessment instruments, followed by a pregnancy and health history, clinical observation and knowledge of possible complications secondary to CZS, present themselves as potential allies in the construction of care $^{(25)}$.

Likewise, professionals highlighted the relevance of considering the main complaint of the family and its perspectives regarding children's evolution. It should be noted that, although the medical and therapeutic needs of children with CZS receive special attention from the health team, families' concerns and priorities also need equal attention ${ }^{(25)}$. However, a study carried out in a reference institution in the health care of women and children with CZS, located in northern Brazil, pointed out that health interventions for this public sometimes remain centered on the disease and the family is still perceived just as information receiver ${ }^{(15)}$.

With a view to providing comprehensive care, collaborative work between professionals with different backgrounds is also 
a favorable element. The joint construction of PTS was identified as an important strategy, which corroborates the findings of a review that pointed out PTS as a tool that favors expanded care strategies, based on articulated health practices that contemplate individuals in their entirety and uniqueness ${ }^{(26)}$. It is noteworthy that PTS must be coordinated by a reference professional, i.e., the one who has the greatest bond with users ${ }^{(27)}$.

The recognition of CZS as a chronic condition by the participants of this study directly reflects on the way they plan care actions, as in these cases, they prioritize practices aimed at promoting quality of life. Although there is little information about the subsequent consequences of CZS, functional and mental disabilities throughout life ${ }^{(28)}$, what is known so far reveals the need to use extensive care approaches to children and their families ${ }^{(25,29)}$.

In this way, the challenge imposed on SUS to offer/carry out shared care actions by professionals working in different health care points is reiterated. This is because these children and their families, although they are monitored in specialized services, also lack actions that include health promotion and care articulated by $\mathrm{PHC}^{(30)}$. However, it is necessary to articulate interventions not only for birth or up to three years of life, provided for in the guidelines for early encouragement, but also for transitions in care, school and leisure services ${ }^{(31-32)}$, in order to address the comprehensiveness that constitutes a basic premise of SUS.

Furthermore, with a view to developing interventions that promote the development of children to their maximum potential, minimize the consequences and substantially contribute to children's quality of life ${ }^{(33)}$, it is necessary to include strategies capable of predicting continuity of actions and encouragement for children at home.

Prenatal exposure to ZIKV can manifest itself in different levels of neurodevelopmental impairment, which leads to early referral for specialized multidisciplinary evaluation and care ${ }^{(34)}$. It should be noted that, although the concept of microcephaly was useful in the early discovery of the syndrome as a marker of brain damage to direct scientific efforts, the literature has already demonstrated the diversity of deleterious effects caused by CZS and the fundamental role of early intervention, in order to promote more effective outcomes in neurodevelopment ${ }^{(35)}$.

In this regard, given the uncertainties about the long-term clinical outcome of these children, it is relevant to continuously monitor the development parameters ${ }^{(32)}$ in addition to follow-up offered in specialized care, since coping with a chronic condition requires continuous, resolute and longitudinal care. Therefore, ensuring this level of care is only possible by offering universal, comprehensive and equitable care, which promotes co-responsibility for care and a path that meets health needs ${ }^{(36)}$.

Professionals revealed that the interventions carried out in specialized care aim to encourage children to perform basic activities of daily living, which corroborates a study carried out in northeastern Brazil, which pointed out that $95 \%$ of children with CZS had extreme difficulty in performing fine motor movements and were not able to use utensils or containers for food, confirming the need for a multidisciplinary approach and interventions with assistive technology ${ }^{(29)}$. This allows us to infer that care needs to encourage children's minimum abilities and skills to carry out these activities, including the necessary adaptations to a new reality.
Therefore, follow-up of actions implemented by health and family team is made possible by strategies that make it possible to measure children's evolution against the proposed therapeutic plan. In this sense, considering the family's perception and feedback can favor the quality of care offered. The family's experiences, especially in the home context, enable the construction of care in which the service responses are consistent with the needs of these families and viable for continuity of care ${ }^{(37)}$.

For this follow-up, participants reported using family records in the home environment, through images and videos, which sometimes constitute an important ally in the construction and validation of care by including information not mentioned during the consultations. Therefore, health care actions cannot be limited to the identification of aspects restricted to rehabilitation spaces, as capturing information about functional adaptation and events that interfere with children's evolution are part of continuous assessment ${ }^{(25)}$.

Furthermore, the exchange of information between the different professionals who follow children and their families was identified as preponderant for continuity of care. Thus, interprofessional communication is essential in the process of integration and co-responsibility of care, in order to establish actions and responsibilities among team members with a view to comprehensive care ${ }^{(38-39)}$.

However, in order to ensure this comprehensive care, a more effective role for nurses also in rehabilitation services becomes substantial. This action certainly occurs, but it manifests itself in a fluid and unrecorded way, which on the one hand possibly prevented more nurses from being identified as providers of continuous care for these children and their families, and on the other hand, that their performance was recognized and therefore referred to by the multidisciplinary team members. Despite this, nurses have been appointed as the articulator of care in different contexts and situations $(8,21,26,40)$.

It should be noted that nurses contribute to the other professionals of the multidisciplinary team in different scenarios and contexts, by building and sharing knowledge, in addition to having great ability to lead teamwork and implement educational and care actions in all life cycles. However, in the context of rehabilitation, it is considered that its role remains undefined and its actions limited in view of its potential ${ }^{(40)}$.

With regard to advances in specific knowledge about CZS, clinical protocols remain fluid, and as neurological and developmental abnormalities expand, skilled care becomes a growing concern $^{(41)}$. Thus, it emphasizes the importance of professionals interest and willingness to seek the necessary knowledge, since the responsibility for training and updating professionals is not restricted to institutional management ${ }^{(21)}$.

It is noteworthy that professionals emphasized the importance of the individual search for knowledge about CZS, the exchange of knowledge between team professionals and practical experience with other diseases that also affect neurodevelopment to support the behaviors given to children and their families. In other words, in addition to recognizing the need for professional training, they highlighted that, faced with a "new" condition, it is important to develop actions already used in the care of children with other diseases with similar clinical manifestations. In this 
sense, a study carried out with researchers from Brazil and Canada reflected on the need to promote evidence-based rehabilitation and ensure the consistent training of health professionals who care for children with $\mathrm{CZS}^{(42)}$.

From professionals' perspective, another aspect that favored knowledge about care actions to be developed/implemented with children with CZS and their families was the performance of students from the multidisciplinary residency and professors at the rehabilitation center. From professionals' perspective, another aspect that favored knowledge about care actions to be developed/implemented with children with CZS and their families was the performance of students from the multidisciplinary residency and professors at the rehabilitation center ${ }^{(43)}$, in addition to encouraging the development of more proposals that enable teaching practices in the light of SUS principles.

In this sense, a study with professionals in the maternal and child area in the United States, working in care services for chronic diseases, emphasized that it was essential to continue to build an interdisciplinary workforce focused on the needs and specificities of children with $\mathrm{CZS}^{(44)}$. Therefore, the desire for qualification in the face of a chronic condition surpasses advances aimed at early diagnosis and intervention by increasing the need to train professionals to provide care that prioritizes the quality of life of this public.

\section{Study limitations}

A possible limitation is related to the non-participation of all professional categories working in the service, especially nurses, as in practice they are coordinators of care actions, act as a bridge between all professionals involved in rehabilitation and have a fundamental role in PTS construction, although this is not always recognized.

\section{Contributions to nursing, health, and public policies}

The knowledge generated can favor the expansion and understanding of the challenges and facilitators for carrying out the care of children with CZS in accordance with SUS principles, by demonstrating that it is necessary to meet the unique needs of these children and their families, in addition to planning and implementing care focused on strengthening bonds, coresponsibility and multi and interprofessional work. Still as a contribution, this study points out the need for improvement of care in the context of rehabilitation, a space in which nursing still needs to take its role in addition to recognizing the importance of recording the actions it develops with these children and their families, especially those who involve lightweight technology as they represent genuine needs.

\section{FINAL CONSIDERATIONS}

The construction of care for children with CZS and their families is made possible by actions guided by the dimension of biopsychosocial aspects and needs that involve coping with a chronic condition, associated with the use of assessment instruments and tools such as PTS in care management. Furthermore, the support of an integrated and qualified team with practices aimed at individual needs of children and their families, with a view to comprehensiveness and continuity of care, were identified as relevant in the consolidation and success of the proposed interventions, as well as the importance of expanding the care network for this child and family, also involving other systems, such as educational, social and leisure.

Children affected by CZS and their families have a future fraught with uncertainty and will face lifelong challenges. For this reason, it is important to know and develop interventions that explore alternative and effective ways of planning and implementing care actions provided by health professionals working in SUS. Therefore, it is necessary to expand the visibility of the aspects that involve individual care in the context of specialized care, and in other health care points, in order to provide assistance in line with SUS principles.

\section{FUNDING AND ACKNOWLEDGMENT}

This study whas financed in part by the Coordenação de Aperfeiçoamento de Pessoal de Nível Superior - Brasil (CAPES) - Finance Code 001.

This the Universidade Federal de Mato Grosso do Sul.

\section{REFERENCES}

1. Moore CA, Staples JE, Dobyns WB, Pessoa A, Ventura CV, Fonseca EB, et al. Congenital zika syndrome: characterizing the pattern of anomalies for pediatric healthcare providers. JAMA Pediatr. 2017;171(3):288-95. https://doi.org/10.1001/jamapediatrics.2016.3982

2. Kelly AH, Lezaun J, Löwy I, Matta GC, Nogueira CO, Rabello ET. Uncertainty in times of medical emergency: Knowledge gaps and structural ignorance during the Brazilian Zika crisis. Soc Sci Med. 2020;246:112787. https://doi.org/10.1016/j.socscimed.2020.112787

3. Mendes AG, Campos DS, Silva LB, Moreira MEL, Arruda LO. Facing a new reality from the Zika Virus Congenital Syndrome: the families' perspective. Cienc Saude Colet. 2020;25(10):3785-94. https://doi.org/10.1590/1413-812320202510.00962019

4. Peiter PC, Pereira RS, Moreira MCN, Nascimento M, Tavares MFL, Franco VC, et al. Zika epidemic and microcephaly in Brazil: challenges for access to health care and promotion in three epidemic areas. PLoS One. 2020;15(7):e0235010. https://doi.org/10.1371/journal. pone. 0235010

5. Dias BC, Ichisato SM, Marchetti MA, Neves ET, Higarashi IH, Marcon SS. Challenges of family caregivers of children with special needs of multiple, complex and continuing care at home. Esc Anna Nery. 2019;23(1):e20180127. https://doi.org/10.1590/2177-9465-EAN-2018-0127

6. Vaz EMC, Collet N, Cursino EG, Forte FDS, Magalhães RKBP, Reichert APS. Care coordination in Health Care for the child/adolescent in chronic condition. Rev Bras Enferm. 2018;71(Suppl 6):2612-9. https://doi.org/10.1590/0034-7167-2017-0787 
7. Souza AP, Rezende K, Marin MJ, Tonhom S. Family health strategy and care integrality: professionals' perception. Rev Baiana Enferm. 2020;34:e34935. https://doi.org/10.18471/rbe.v34.34935

8. Furtado MCDC, Mello DF, Pina JC, Vicente JB, Lima PR, Rezende VD. Nurses' actions and articulations in child care in primary health care. Texto Contexto Enferm. 2018;27(1):e0930016. https://doi.org/10.1590/0104-07072018000930016

9. Siddique R, Liu Y, Nabi G, Sajjad W, Xue M, Khan S. Zika virus potentiates the development of neurological defects and microcephaly: challenges and control strategies. Front Neurol. 2019;10:319. https://doi.org/10.3389/fneur.2019.00319

10. Casale TB, Teng MN, Morano JP, Unnasch T, Lockwood CJ. Zika virus: an emerging infectious disease with serious perinatal and neurologic complications. J Allergy Clin Immunol. 2018;141(2):482-90. https://doi.org/10.1016/j.jaci.2017.11.029

11. Karkhah A, Nouri HR, Javanian M, Koppolu V, Masrour-Roudsari J, Kazemi S, et al. Zika virus: epidemiology, clinical aspects, diagnosis, and control of infection. Eur J Clin Microbiol Infect Dis. 2018;37(11):2035-43. https://doi.org/10.1007/s10096-018-3354-z

12. Escosteguy CC, Medronho RE, Rodrigues RC, Silva LDR, Oliveira BA, Machado FB, et al. Microcefalia e alterações do sistema nervoso central relacionadas à infecção congênita pelo vírus Zika e outras etiologias infecciosas no estado do Rio de Janeiro: estudo transversal, 2015 a 2017. Rev Panam Salud Publica. 2020;44:e151. https://doi.org/10.26633/ RPSP.2020.151

13. Gomez HM, Mejia Arbelaez C, Ocampo Cañas JA. A qualitative study of the experiences of pregnant women in accessing healthcare services during the Zika virus epidemic in Villavicencio, Colombia, 2015-2016. Int J Gynaecol Obstet. 2020;148(Suppl 2):29-35. https://doi. org/10.1002/ijgo.13045

14. Marbán-Castro E, Villén-Gonzalvo A, Enguita-Fernàndez $C$, Marín-Cos $A$, Menéndez $C$, Maixenchs $M$, et al. Uncertainties, fear and stigma: perceptions of Zika virus among pregnant women in Spain. Int J Environ Res Public Health. 2020;17(18):6643. https://doi.org/10.3390/ ijerph17186643

15. Silva DA, Silva ÉQ. Saúde mental no enfoque das mulheres afetadas pelo Zika vírus: um estudo etnográfico no Estado do Pará, Brasil. Cad Saude Publica. 2020;36(8):e00100019. https://doi.org/10.1590/0102-311×00100019

16. Hamad GBNZ, Souza KVD. Special child, special mother: the sense of strength in mothers of children with congenital zika vírus syndrome. Esc Anna Nery. 2019;23(4):e20190022. https://doi.org/10.1590/2177-9465-EAN-2019-0022

17. Minayo MCS. Amostragem e saturação em pesquisa qualitativa: consensos e controvérsias. Rev Pesqui Qual [Internet]. 2017 [cited 2021 Feb 18];5(7):01-12. Available from: https://editora.sepq.org.br/rpq/article/view/82

18. Bardin L. Análise de conteúdo. Lisboa: Edições 70; 2016.

19. Kuper $\mathrm{H}$, Smythe T, Duttine A. Reflections on health promotion and disability in low and middle-income countries: case study of parentsupport programmes for children with congenital Zika syndrome. Int J Environ Res Public Health. 2018;15(3):514. https://doi.org/10.3390/ ijerph15030514

20. Moreira MCN, Albernaz LV, Sá MRC, Correia RF, Tanabe RF. Guidelines for a line of care for children and adolescentes with complex chronic health conditions. Cad Saude Publica. 2017;33(11):e00189516. https://doi.org/10.1590/0102-311X00189516

21. Favaro LC, Marcon SS, Nass EMA, Reis P, Ichisato SMT, Bega AG, et al. Percepção do enfermeiro sobre assistência às crianças com necessidades especiais de saúde na atenção primária. REME. 2020;24:e-1277. https://doi.org/10.5935/1415-2762.20200006

22. Duttine A, Smythe T, Sá MRC, Ferrite S, Zuurmond M, Moreira ME, et al. Congenital Zika Syndrome-Assessing the Need for a Family Support Programme in Brazil. Int J Environ Res Public Health. 2020;17(10):3559. https://doi.org/10.3390/ijerph17103559

23. Albuquerque MSV, Lyra TM, Melo APL, Valongueiro SA, Araújo TVB, Pimentel C, et al. Access to healthcare for children with Congenital Zika Syndrome in Brazil: perspectives of mothers and health professionals. Health Policy Plan. 2019;34(7):499-507. https://doi.org/10.1093/ heapol/czz059

24. Barreiros CFC, Gomes MASM, Mendes Júnior SCS. Children with special needs in health: challenges of the single health system in the 21 st century. Rev Bras Enferm. 2020;73(Suppl 4):e20190037. https://doi.org/10.1590/0034-7167-2019-0037

25. Bailey DB Jr, Ventura LO. The likely impact of congenital Zika syndrome on families: considerations for family supports and services. Pediatrics. 2018;141(Suppl 2):S180-7. https://doi.org/10.1542/peds.2017-2038G

26. Rocha EN, Lucena AF. Single Therapeutic Project and Nursing Process from an interdisciplinary care perspective. Rev Gaucha Enferm. 2018;39:e20170057. https://doi.org/10.1590/1983-1447.2018.2017-0057

27. Baptista JÁ, Camatta MW, Filippon PG, Schneider JF. Singular therapeutic project in mental health: na integrative review. Rev Bras Enferm. 2020;73(2):e20180508. https://doi.org/10.1590/0034-7167-2018-0508

28. Miranda RN, Ximenes R, Gebretekle GB, Bielecki JM, Sander B, RADAM-LAC Research Team. Health-related quality of life in neurological disorders most commonly associated with Zika-virus infection: a systematic review. Value Health. 2020;23(7):969-976. https://doi. org/10.1016/j.jval.2020.03.004

29. Ferreira HNC, Schiariti V, Regalado ICR, Sousa KG, Pereira SA, Fechine CPNS, et al. Functioning and disability profile of children with microcephaly associated with congenital Zika virus infection. Int J Environ Res Public Health. 2018;15(6):1107. https://doi.org/10.3390/ ijerph15061107

30. Marcon SS, Dias BC, Neves ET, Marcheti MA, Lima RAG. (In)visibility of children with special health needs and their families in primary care. Rev Bras Enferm. 2020;73(Supp4):e20190071. https://doi.org/10.1590/0034-7167-2019-0071 
31. Ministério da Saúde (BR). Diretrizes de estimulação precoce: crianças de zero a 3 anos com atraso no desenvolvimento neuropsicomotor. Brasília, DF: MS [Internet];2016 [cited 2021 Feb 19]. Available from: https://bvsms.saude.gov.br/bvs/publicacoes/diretrizes_estimulacao_ criancas_0a3anos_neuropsicomotor.pdf

32. Porter S, Mimm N. Infants with congenital Zika virus infection: a new challenge for early intervention professionals. Infants Young Child. 2017;30(1):17-27. https://doi.org/10.1097/IYC.00000000000000084

33. Dantas MSA, Nobrega VM, Fechine CPNS, Torquato IMB, Assis WD, Collet N. Professional care for children with cerebral palsy and their families. Rev Enferm UERJ. 2017;25:e18331. https://doi.org/10.12957/reuerj.2017.18331

34. Silva PFS, Eickmann SH, Ximenes RAA, Montarroyos UR, Lima MC, Martelli CMT, et al. Pediatric neurodevelopment by prenatal Zika virus exposure: a cross-sectional study of the Microcephaly Epidemic Research Group Cohort. BMC Pediatr. 2020;20:472. https://doi.org/10.1186/ s12887-020-02331-2

35. Waldorf KMA, Olson EM, Nelson BR, Little M-E, Rajagopal L. The aftermath of Zika: need for long-term monitoring of exposed children. Trends Microbiol. 2018;26(9):729-32. https://doi.org/10.1016/j.tim.2018.05.011

36. Ministério da Saúde (BR). Portaria ${ }^{\circ}$ 2.436, de 21 de setembro de 2017. Aprova a Política Nacional de Atenção Básica, estabelecendo a revisão de diretrizes para a organização da Atenção Básica, no âmbito do Sistema Único de Saúde (SUS). Brasília, DF: MS [Internet]; 2017[cited 2021 Feb 19]. Available from: https://bvsms.saude.gov.br/bvs/saudelegis/gm/2017/prt2436_22_09_2017.html

37. Sá FE, Andrade MMG, Nogueira EMC, Lopes JSM, Silva APÉP, Assis AMV. Parental needs in the care for children with Zika virus-induced microcephaly. Rev Bras Promoc Saude. 2017;30(4):1-10. https://doi.org/10.5020/18061230.2017.6629

38. Ratna H. The Importance of effective communication in healthcare practice. Harv Public Health Rev (Camb). 2019[cited 2021 Feb 18];23:1-6. Available from: https://www.jstor.org/stable/48546767

39. Delmiro ARCA, Pimenta EAG, Nóbrega VM, Fernandes LTB, Barros GC. Equipe multiprofissional no preparo para a alta hospitalar de crianças com condições crônicas. Cienc Cuidado Saúde. 2020;19:e50418. https://doi.org/10.4025/cienccuidsaude.v19i0.50418

40. Silva NRN, Macêdo AC, Melo GC, Duprat IP, Santos Sobrinha ES, Silva ALOB, et al. Atuação do enfermeiro na reabilitação da saúde da pessoa com deficiência. Rev Eletron Acervo Sade. 2021;13(2):e5888. https://doi.org/10.25248/reas.e5888.2021

41. Sá MRC, Vieira ACD, Castro BSM, Agostini O, Smythe T, Kuper H, et al. The need to act together in every way possible: inter-sector action in health and education for children living with the congenital Zika syndrome. Cad Saude Publica. 2019;35(12):e00233718. https://doi. org/10.1590/0102-311x00233718

42. Longo E, Campos AC, Schiariti V. Zika Virus After Emergency Response: Can the ICF Guide Rehabilitation of Children With Microcephaly?. Pediatr Phys Ther. 2019;31(4):370-2. https://doi.org/10.1097/PEP.0000000000000647

43. Silveira JLGC, Kremer MM, Silveira MEUC, Schneider ACTC. Percepções da integração ensino-serviço-comunidade: contribuições para a formação e o cuidado integral em saúde. Interface (Botucatu). 2020;24:e190499. https://doi.org/10.1590/interface.190499

44. Zai T, Yasuda PM, Rao S, lizumi S, Vanderbilt DL, Deavenport-Saman A. Assessing the quality of the systems of care for children with congenital Zika virus infection and other neurodevelopmental disabilities in the United States pacific island territories. Hawaii J Health Soc Welf [Internet]. 2020[cited 2021 Feb 18];79(9):279-284. Available from: https://www.ncbi.nlm.nih.gov/pmc/articles/PMC7477700/ 